\title{
Catabolic Rate of Low Density Lipoprotein Is Influenced by Variation in the Apolipoprotein B Gene
}

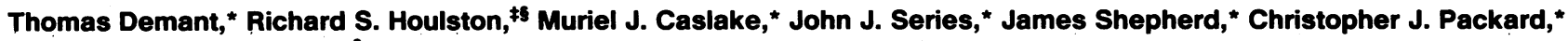 \\ and Stephen E. Humphries \\ ${ }^{*}$ Department of Pathological Biochemistry, Royal Infirmary, Glasgow, G4 OSF Scotland; ${ }^{\ddagger}$ Department of Metabolic Disorders and \\ Chemical Pathology, St. Thomas's Hospital Medical School, London, SE1 7EH, England; and ${ }^{\S}$ Charing Cross Sunley Research Centre, \\ Hammersmith, London, W6 8LW England
}

\begin{abstract}
This study examines the potential influence of genetic variation on the metabolism of LDL. Restriction fragment length polymorphisms (RFLP) of the gene coding for apo $B$ were identified using the endonucleases Xba I, Eco RI, and Msp I in a group of 19 subjects with moderate hyperlipidemia. There was a significant association between the Xba I polymorphism and the total fractional clearance rate (FCR) of LDL. The individuals with the $X 1 X 1$ genotype had, on average, a 22\% higher FCR $(P<0.025)$ than those with the genotype $X 2 X 2$ ( $X 2$ allele $=$ presence of $X b a I$ cutting site). Thís difference was attributable to increased clearance by the receptor-mediated pathway of LDL catabolism. In this group of subjects, there was no association of LDL kinetic parameters and RFLPs of the LDL receptor gene or the AI- CIII- AIV gene cluster. The data suggest that variation in apo B itself, presumably acting through variable binding to the $L D L$ receptor, makes a significant contribution to the rate of catabolism of LDL.
\end{abstract}

\section{Introduction}

Apo B, the major protein component of LDL, contains the binding site for the LDL receptor and consequently plays a pivotal role in the metabolism of the lipoprotein, by facilitating its cellular uptake and degradation $(1,2)$. In recent years, attention has focused on the receptor as the mediator of cholesterol homeostasis in the body, and we now know that a variety of mutations in this protein may produce gross disturbances in plasma LDL levels $(3,4)$. Now, with the isolation of the gene coding for apo B (5), we are able to use the techniques of molecular biology to analyze the contribution that the ligand might make to alterations in lipoprotein metabolism.

DNA probes for the human apo B gene have recently been isolated (6-9) and a number of common restriction fragment length polymorphisms (RFLP) ${ }^{1}$ have been described (9-11).

Address reprint requests to Dr. James Shepherd, Department of Pathological Biochemistry, Royal Infirmary, Glasgow, G4 OSF, Scotland.

A preliminary abstract of this work has been published in 1987 . (Atherosclerosis 68:273.)

Received for publication 19 October 1987 and in revised form 11 April 1988.

1. Abbreviations used in this paper: FCR, fractional clearance rate; RFLP, restriction fragment length polymorphism.

J. Clin. Invest.

(c) The American Society for Clinical Investigation, Inc.

0021-9738/88/09/0797/06 \$2.00

Volume 82, September 1988, 797-802
One of these, an RFLP detected using the restriction enzyme $\mathrm{Xba} \mathrm{I}$, has been shown in normal individuals to be associated with variations in plasma cholesterol and triglyceride (12-14). The same polymorphism has also been reported to represent an independent risk factor for ischemic heart disease (15), although there is not universal agreement on this point (16). In this study, we use three polymorphisms of the apo B gene locus to examine the relationship between variation in the apo B gene and the metabolism of LDL in a group of individuals with moderate hyperlipemia.

\section{Methods}

Subjects. Volunteers aged between 40 and $60 \mathrm{yr}$ were identified as hyperlipidemic during an opportunistic screening program in the city of Glasgow. Those detected were given dietary advice designed to correct their lipid abnormality and reassessed after 2 mo. At this point, potential sufferers from familial hypercholesterolemia were diagnosed on the basis of recognized criteria (17) and excluded if they had tendon xanthomata or a first-degree relative (particularly a child) with raised LDL cholesterol. Two subjects with total cholesterol values of 8.5 and $8.3 \mathrm{mmol} /$ liter were rejected on this basis. None of the remaining 19 unrelated Caucasian subjects ( 4 male, 15 female; Table I) who failed to respond adequately to the diet, had a strong family history of premature cardiovascular disease (i.e., more than one affected first-degree relative aged $<55 \mathrm{yr}$ ). Two presented with xanthelasmata, two with corneal arcus, and two with angina of effort (Table I). Their plasma cholesterol levels were, on average, $7.69 \pm 0.73 \mathrm{mmol} / \mathrm{liter}$ and their diet was maintained during the evaluation of LDL metabolic parameters. $60 \mathrm{mg}$ potassium iodide was given thrice daily for $3 \mathrm{~d}$ before and 2 wk after the study to prevent thyroidal sequestration of radioiodide. Biochemical tests showed that none of the subjects suffered from hepatic, renal, or endocrine disease and none had overt ischemic heart disease. All subjects gave informed consent to the study, which was approved by the Ethical Committee of Glasgow Royal Infirmary.

Metabolic studies. LDL turnover was assessed in the patients using a protocol described elsewhere $(18,19)$. Briefly, autologous LDL ( $d$ $=1.03-1.05 \mathrm{~kg} /$ liter) was prepared by rate zonal ultracentrifugation (20) and divided into two aliquots, which were labeled separately with ${ }^{125} I$ and ${ }^{131} I(21)$. The latter was then subjected to modification with 1, 2-cyclohexanedione, which blocks the arginyl residues on its protein moiety (22) and provides a tracer of receptor-independent LDL metabolism $(18,19)$. Such modification prevents interaction of the lipoprotein with the receptor and denies it access to the receptor-dependent degradation pathway. Plasma clearance of each tracer was followed over a 2-wk period and the radioactive decay curves were constructed and analyzed using the SAAM 29 computer program (23). This gave fractional clearance rates (FCRs) for the native and chemically modified LDL that were used to obtain values for total, receptor-independent, and, by difference, receptor-mediated catabolism of the lipoprotein $(18,19)$. Plasma apo LDL concentrations were determined from calculations based on serial LDL cholesterol measurements and on compositional data derived from analyses of the isolated lipoprotein (24). The absolute clearance rate for LDL apoprotein was then calculated as the product of the total FCR and the plasma LDL pool (i.e., 
apo LDL concentration times the plasma volume). This parameter is commonly expressed per kilogram of body weight, and under the steady state conditions of the study equals the synthetic rate of the protein. Separate absolute clearance rates can also be calculated for the receptor-dependent and independent routes as the product of the apo LDL pool and the FCR can be determined for each pathway.

DNA analysis. Blood was collected into $2.0 \mathrm{mg} / \mathrm{ml} \mathrm{K}_{2}$ EDTA and stored at $-20^{\circ} \mathrm{C}$ until analysis. DNA was prepared from these specimens by the Triton X100 lysis method (25), and a 5.0- $\mu$ g aliquot was digested using a panel of enzymes (Eco RI, Xba I, Pvu II, Xmn I, and Nco I) at 2-10 U of enzyme per microgram of DNA according to the supplier's instructions (Anglian Biotech, Colchester, England).

The fragments generated in each digest were separated by agarose electrophoresis and transferred to Hybond filters (Amersham Corp., Amersham, England) by Southern blotting.

Polymorphisms of the apo B gene were detected (Fig. 1): (a) by hybridizing the two Xba I digest fragments designated $X 1(8.6 \mathrm{~kb})$ and $X 2(3.5 \mathrm{~kb})$, with the $3.5-\mathrm{kb}$ probe pABC3.5 (11); $(b)$ in an Eco RI digest by hybridizing the two fragments, $R I(10.5 \mathrm{~kb})$ and $R 2(12.5 \mathrm{~kb})$, with the cDNA probe $\mathrm{pAB} 3(11)$; and $(c)$ after digestion with Msp I and probing with PH2 (a 2-kb Hind III fragment subcloned from an apo B genomic recombinant). Multiple hybridizing fragments could be demonstrated (11). Those $2.6 \mathrm{~kb}$ and larger were designated $M I$ and those $2.2 \mathrm{~kb}$ and smaller were designated M2. Polymorphisms of the LDL receptor gene were detected using a 1.9-kb Bam HI cDNA $(26,27)$ after digestion with either Pvu II or Nco I.

Apolipoprotein AI/CIII/AIV gene cluster polymorphisms were identified using (a) a 2.2-kb Pst I fragment (28) of the apo AI gene after Xmn I digestion and (b) a 1.0-kb Pvu II fragment (29) of the C-III gene after Pvu II digestion.

All probes were labeled with ${ }^{32} \mathrm{P}$ dCTP at a specific activity of 800 $\mathrm{Ci} / \mathrm{mmol}$ (Amersham Corp.) by a random oligonucleotide priming method (30). The hybridization, filter washing, and autoradiographic procedures are described elsewhere (28).

Statistical analysis. Statistical analysis was carried out by the Minitab program (State College, PA). A one-way analysis of variance was performed to test the null hypothesis that kinetic variation was not associated with genetic variation detected by the different RFLPs. The $F$ statistic was employed to test the significance of differences between the genotypes. We considered significance to be at the 0.05 level.

\section{Results}

The 19 subjects could be divided into three groups on the basis of the polymorphisms detected using the Xba I endonuclease
(Table I). There was no difference in body weight or mean age, nor in the plasma concentrations of cholesterol, triglyceride, LDL cholesterol, or apoprotein between those with the genotype $X I X I$ (absence of cutting site) and those with the genotype $X 2 X 2$. There were also no significant differences in these parameters when the subjects were grouped according to the polymorphisms detected with the Msp I and the Eco RI enzymes. Similarly, the gross composition of LDL was not altered in individuals of different Xba I genotype (Table II).

However, the metabolic properties of LDL did differ between the genotype groups. The catabolic rate of LDL apoprotein measured as the fraction of the plasma pool catabolized each day (FCR), was significantly higher in individuals with the $X 1 X 1$ genotype compared with those with $X 2 X 2$ (F $=9.18 ; P<0.025)$. The subjects with the genotype $X 1 X 2$ had an intermediate mean FCR. Simultaneous with the, injection of native lipoprotein, subjects received a tracer of cyclohexanedione-treated LDL that permitted the estimation of receptor-dependent versus receptor-independent removal (Table III). This revealed that the difference in overall catabolism was due to an increase in the fraction and amount of LDL degraded by the receptor route. Subjects of $X 1 X 1$ genotype exhibited a $58 \%$ higher receptor-mediated FCR than those with the genotype $X 2 X 2(F=9.08 ; P<0.025)$ and cleared $65 \%$ more LDL protein through this pathway. No such difference was observed in the fraction of LDL degraded by receptor-independent mechanisms. Likewise, when the synthetic rate of LDL apoprotein was calculated, no significant association with genotype was observed, although this parameter was highly variable within the groups.

There was a weak association between LDL apoprotein clearance rate and the apo $B$ polymorphism detected using Msp I (Table IV), but the differences did not reach statistical significance. In the 19 subjects examined, LDL kinetic parameters were not significantly different in individuals with different RFLP genotypes of the LDL-receptor gene or the AI-CIIIAIV gene cluster (data not shown).

\section{Discussion}

The individuals examined in this study had diet-refractory hyperlipidemia that arose from a combination of oversynthesis

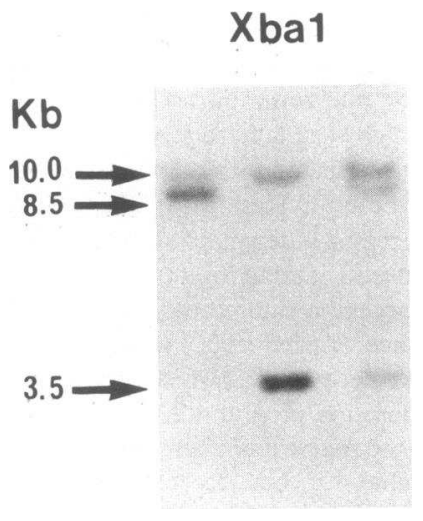

$\times 1 \times 1 \times 2 \times 2 \times 1 \times 2$

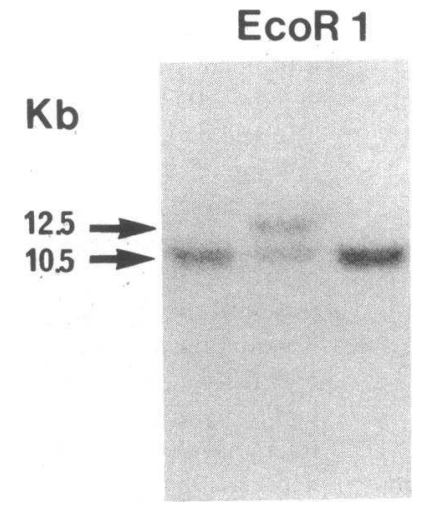

R1R1 R1R2 R1R1

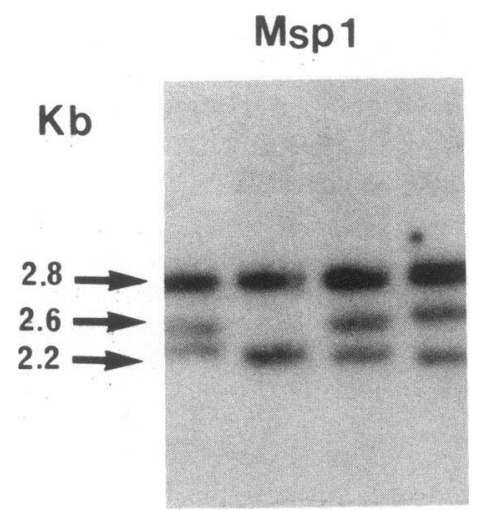

M1M2 M2M2 M1M2 M1M2

Figure 1. Southern blot analysis of the Xba I, Eco RI, and Msp I polymorphism of the apo B gene. $5 \mu \mathrm{g}$ of DNA from three individuals is shown. The Msp I polymorphism is a length variation due to different numbers of copies of a 14-bp repeat sequence in the $3^{\prime}$ flanking region of the gene (36). 


\begin{tabular}{|c|c|c|c|c|c|c|}
\hline \multirow[b]{2}{*}{ Subject } & \multirow[b]{2}{*}{ Genotype } & \multicolumn{2}{|c|}{ Plasma } & \multirow[b]{2}{*}{ LDL-cholesterol } & \multirow[b]{2}{*}{ LDL-apoprotein } & \multirow[b]{2}{*}{ Clinical data } \\
\hline & & Cholesterol & Triglyceride & & & \\
\hline & & & mmol/liter & & $m g / d l$ & \\
\hline 1 & $\mathrm{X} 1 \mathrm{X} 1$ & 8.10 & 1.95 & 5.90 & 193 & Angina \\
\hline 2 & $\mathbf{X} 1 \mathbf{X} 1$ & 7.74 & 1.24 & 5.99 & 192 & Xanthelasmata \\
\hline 3 & $\mathrm{X} 1 \mathrm{X} 1$ & 6.89 & 1.66 & 4.93 & 149 & Normal \\
\hline 4 & $\mathbf{X} 1 \mathbf{X} 1$ & 8.49 & 3.24 & 6.28 & 211 & Corneal arcus \\
\hline 5 & $\mathbf{X} 1 \mathbf{X} 1$ & 7.08 & 1.43 & 5.28 & 179 & Normal \\
\hline$n=5$ & Mean \pm 1 SD & $7.76 \pm 0.59$ & $1.88 \pm 0.65$ & $5.73 \pm 0.47$ & $187 \pm 19$ & \\
\hline 6 & $\mathrm{X} 1 \mathrm{X} 2$ & 8.09 & 1.20 & 5.76 & 151 & Normal \\
\hline 7 & $\mathrm{X} 1 \mathrm{X} 2$ & 8.79 & 1.90 & 6.63 & 204 & Normal \\
\hline 8 & $\mathrm{X} 1 \mathrm{X} 2$ & 7.12 & 2.60 & 4.80 & 173 & Normal \\
\hline 9 & $\mathrm{X} 1 \mathrm{X} 2$ & 6.97 & 1.80 & 4.99 & 167 & Angina \\
\hline 10 & $\mathrm{X} 1 \mathrm{X} 2$ & 8.09 & 2.31 & 6.01 & 174 & $\begin{array}{l}\text { Myocardial infarction in mother } \\
\text { (age 55) }\end{array}$ \\
\hline 11 & $\mathrm{X} 1 \mathrm{X} 2$ & 6.85 & 0.83 & 3.76 & 156 & Normal \\
\hline 12 & $\mathrm{X} 1 \mathrm{X} 2$ & 7.05 & 2.14 & 4.75 & 135 & Normal \\
\hline 13 & $\mathrm{X} 1 \mathrm{X} 2$ & 8.53 & 2.15 & 6.58 & 186 & $\begin{array}{l}\text { Myocardial infarction in brother } \\
\text { (age 54) }\end{array}$ \\
\hline$n=8$ & Mean \pm 1 SD & $7.69 \pm 0.72$ & $1.87 \pm 0.55$ & $5.41 \pm 0.94$ & $168 \pm 20$ & \\
\hline 14 & $\mathrm{X} 2 \mathrm{X} 2$ & 8.33 & 2.23 & 5.46 & 253 & Arcus \\
\hline 15 & $\mathrm{X} 2 \mathrm{X} 2$ & 8.56 & 2.76 & 6.20 & 175 & $\begin{array}{l}\text { Myocardial infarction in father } \\
\text { (age 45) }\end{array}$ \\
\hline 16 & $\mathrm{X} 2 \mathrm{X} 2$ & 6.36 & 0.82 & 3.79 & 146 & Normal \\
\hline 17 & $\mathrm{X} 2 \mathrm{X} 2$ & 8.00 & 3.11 & 5.62 & 176 & Normal \\
\hline 18 & $\mathrm{X} 2 \mathrm{X} 2$ & 7.03 & 1.68 & 4.88 & 160 & Xanthelasmata \\
\hline 19 & $\mathrm{X} 2 \mathrm{X} 2$ & 8.09 & 2.57 & 5.84 & 192 & Normal \\
\hline$n=6$ & Mean \pm 1 SD & $7.73 \pm 0.78$ & $2.32 \pm 0.77$ & $5.30 \pm 0.78$ & $184 \pm 34$ & \\
\hline
\end{tabular}

All values given in the table are means of at least three independent determinations. Analysis of variance showed no significant differences in plasma lipid parameters between any of the three groups (X1X1, X1X2, or X2X2).

and defective catabolism. Most had LDL apoprotein synthetic rates (Table III) in excess (31-33) of normal values (11-13 $\mathrm{mg} / \mathrm{kg}$ per d), whereas their total LDL FCRs lay between the values observed $(32,33)$ in controls $(0.35 \pm 0.06$ pools $/ \mathrm{d})$ and those $(18,31)$ in familial hypercholesterolemia heterozygotes $(0.19 \pm 0.046$ pools/d) that have only a partial complement of LDL receptors. They also exhibited reduced receptor-mediated FCRs that varied from 9 to $39 \%$ of the total. This is lower than the $50 \%$ we have previously observed in normolip- idemic controls $(33,34)$ because of the general inverse relationship between plasma LDL concentration and receptor activity (31). Note also that there are differences seen in the estimated contribution of the receptor pathway when alternative methods of modifying LDL are used. For example, Kesaniemi et al. (35) reported much higher values for receptormediated clearance using glucosylated LDL. The relative merits of the different approaches have been discussed in detail (34).

Table II. LDL Composition in Individuals with Different Apo B Xba I Genotype

\begin{tabular}{cccccc}
\hline & \multicolumn{5}{c}{ LDL composition } \\
\cline { 2 - 5 } Genotype & Free cholesterol & Esterified cholesterol & Triglyceride & Phospholipid & Protein \\
\hline & & & $8 / 100 g$ & & \\
X1X1 $(n=5)$ & $9.29 \pm 0.81^{*}$ & $36.93 \pm 2.77$ & $8.06 \pm 0.99$ & $20.52 \pm 0.35$ & $25.21 \pm 1.15$ \\
X1X2 $(n=8)$ & $9.25 \pm 0.77$ & $38.26 \pm 1.93$ & $7.02 \pm 1.28$ & $21.43 \pm 1.29$ & $23.91 \pm 0.72$ \\
X2X2 $(n=6)$ & $8.42 \pm 0.80$ & $37.64 \pm 1.34$ & $7.26 \pm 0.73$ & $20.97 \pm 0.58$ & $25.69 \pm 1.73$ \\
\hline
\end{tabular}

No significant differences were present in composition between any of the three groups.

* Mean \pm 1 SD. 
Table III. LDL-Kinetic Parameters and Xba I Genotype

\begin{tabular}{|c|c|c|c|c|c|c|c|c|}
\hline \multirow[b]{2}{*}{ Subject } & \multirow[b]{2}{*}{ Sex } & \multicolumn{3}{|c|}{ RFLP genotypes } & \multicolumn{2}{|c|}{ Fractional catabolic rate } & \multirow[b]{2}{*}{ Synthesis* } & \multirow{2}{*}{$\begin{array}{l}\text { Absolute }^{\ddagger} \\
\text { receptor-mediated } \\
\text { catabolic rate }\end{array}$} \\
\hline & & Xba I & Eco RI & Msp I & Total & Receptor mediated & & \\
\hline & & & & & \multicolumn{2}{|c|}{ pools/d } & \multicolumn{2}{|c|}{$m g / k g$ per $d$} \\
\hline 1 & $\mathbf{F}$ & $\mathbf{X} 1 \mathbf{X} 1$ & RIR1 & M1M2 & 0.248 & 0.088 & 19.10 & 6.80 \\
\hline 2 & $\mathrm{~F}$ & $\mathrm{X} 1 \mathrm{X} 1$ & R1R2 & M1M2 & 0.256 & 0.101 & 19.70 & 7.80 \\
\hline 3 & $\mathrm{~F}$ & $\mathrm{X} 1 \mathrm{X} 1$ & R1R1 & M2M2 & 0.270 & 0.079 & 16.10 & 4.71 \\
\hline 4 & $\mathbf{F}$ & $\mathrm{X} 1 \mathrm{X} 1$ & R1R1 & M1M2 & 0.282 & 0.069 & 23.80 & 5.82 \\
\hline 5 & $\mathbf{M}$ & $\mathbf{X} 1 \mathbf{X} 1$ & R1R2 & M1M2 & 0.297 & 0.072 & 21.27 & 5.16 \\
\hline$n=5$ & & & \multicolumn{2}{|c|}{ Mean \pm 1 SD } & $0.271 \pm 0.020$ & $0.082 \pm 0.013$ & $19.99 \pm 2.84$ & $6.06 \pm 1.25$ \\
\hline 6 & $\mathrm{~F}$ & $\mathrm{X} 1 \mathrm{X} 2$ & R1R2 & M1M2 & 0.219 & 0.078 & 13.23 & 4.71 \\
\hline 7 & $\mathrm{~F}$ & $\mathrm{X} 1 \mathrm{X} 2$ & RIR1 & M2M2 & 0.229 & 0.087 & 18.69 & 7.10 \\
\hline 8 & $\mathrm{~F}$ & $\mathrm{X} 1 \mathrm{X} 2$ & R1R2 & & 0.252 & 0.022 & 17.40 & 1.50 \\
\hline 9 & $\mathrm{~F}$ & $\mathrm{X} 1 \mathrm{X} 2$ & R1R2 & M1M2 & 0.251 & 0.044 & 16.80 & 2.90 \\
\hline 10 & $\mathrm{~F}$ & $\mathrm{X} 1 \mathrm{X} 2$ & R1R1 & M1M2 & 0.241 & 0.070 & 16.77 & 4.87 \\
\hline 11 & $\mathrm{~F}$ & $\mathrm{X} 1 \mathrm{X} 2$ & R1R2 & M1M2 & 0.218 & 0.084 & 13.60 & 5.20 \\
\hline 12 & $\mathbf{M}$ & $\mathrm{X} 1 \mathrm{X} 2$ & R1R2 & M1M2 & 0.280 & 0.114 & 15.12 & 6.16 \\
\hline 13 & $\mathbf{M}$ & $\mathrm{X} 1 \mathrm{X} 2$ & R1R1 & M2M2 & 0.205 & 0.056 & 15.25 & 4.16 \\
\hline$n=8$ & & & \multicolumn{2}{|c|}{ Mean \pm 1 SD } & $0.237 \pm 0.024$ & $0.069 \pm 0.028$ & $15.86 \pm 1.89$ & $4.58 \pm 1.77$ \\
\hline 14 & $F$ & $\mathrm{X} 2 \mathrm{X} 2$ & R1R1 & & 0.218 & 0.020 & 22.10 & 2.00 \\
\hline 15 & $\mathbf{M}$ & $\mathrm{X} 2 \mathrm{X} 2$ & $\mathbf{R} 1 \mathbf{R} 1$ & M2M2 & 0.197 & 0.067 & 13.79 & 4.69 \\
\hline 16 & $F$ & $\mathrm{X} 2 \mathrm{X} 2$ & $\mathbf{R} 1 \mathbf{R} 1$ & M2M2 & 0.182 & 0.042 & 10.60 & 2.50 \\
\hline 17 & $\mathrm{~F}$ & $\mathrm{X} 2 \mathrm{X} 2$ & R1R1 & M2M2 & 0.265 & 0.054 & 18.66 & 3.80 \\
\hline 18 & $\mathbf{F}$ & $\mathrm{X} 2 \mathrm{X} 2$ & R1R1 & M2M2 & 0.217 & 0.070 & 13.90 & 4.50 \\
\hline 19 & $\mathbf{F}$ & $\mathrm{X} 2 \mathrm{X} 2$ & RIR1 & M2M2 & 0.250 & 0.059 & 19.20 & 4.53 \\
\hline$n=6$ & & & \multicolumn{2}{|c|}{ Mean \pm 1 SD } & $0.222 \pm 0.031$ & $0.052 \pm 0.019$ & $16.38 \pm 4.29$ & $3.67 \pm 1.15$ \\
\hline \multirow{2}{*}{\multicolumn{2}{|c|}{$\begin{array}{c}\text { Analysis of } \\
\text { variance }\end{array}$}} & \multirow{2}{*}{\multicolumn{3}{|c|}{$\begin{array}{l}\mathrm{X} 1 \mathrm{X} 1: \mathrm{X} 1 \mathrm{X} 2: \mathrm{X} 2 \mathrm{X} 2 \\
\mathrm{X} 1 \mathrm{X} 1: \mathrm{X} 2 \mathrm{X} 2\end{array}$}} & $P<0.025$ & NS & NS & $P<0.050$ \\
\hline & & & & & $P<0.025$ & $P<0.025$ & NS & $P<0.010$ \\
\hline
\end{tabular}

No significant differences could be detected when genotypically different groups (R1R1 versus R1R2; M1M2 versus M2M2) were compared by analysis of variance. * The synthetic rate is equal to the product of the total FCR and the plasma LDL pool (LDL concentration $\times$ plasma volume). ${ }^{\ddagger}$ The absolute receptor-mediated catabolic rate is the product of the receptor-mediated FCR and the plasma LDL pool.

It is difficult to make a definitive diagnosis of familial hypercholesterolemia in individuals with moderately elevated cholesterol levels using available techniques. Clinical criteria remain the best guide, but even here, lack of available family history may cloud the issue. In this study, commonly accepted exclusion criteria were set for individuals with familial hyper- cholesterolemia (see Methods). However, it is important to note in interpreting the data that these criteria are not absolute.

Although individuals with familial hypercholesterolemia were excluded from the study and all of the subjects had similar plasma lipid and lipoprotein levels, the FCR for LDL var-

Table IV. LDL Kinetic Parameters and Eco RI and Msp I RFLP Genotypes

\begin{tabular}{|c|c|c|c|c|}
\hline \multirow[b]{2}{*}{ Genotype } & \multicolumn{2}{|c|}{ Fractional catabolic rate } & \multirow[b]{2}{*}{ Synthesis* } & \multirow{2}{*}{$\begin{array}{l}\text { Absolute }{ }^{q} \text { receptor-mediated } \\
\text { catabolic rate }\end{array}$} \\
\hline & Total & Receptor mediated & & \\
\hline & \multicolumn{2}{|c|}{ pools/d } & \multicolumn{2}{|c|}{$m g / k g$ per $d$} \\
\hline \multicolumn{5}{|l|}{ Eco RI-RFLP } \\
\hline R1R1 $n=12$ & $0.234 \pm 0.031$ & $0.063 \pm 0.019$ & $17.33 \pm 3.70$ & $4.62 \pm 1.50$ \\
\hline R1R2 $n=7$ & $0.253 \pm 0.029$ & $0.074 \pm 0.032$ & $16.73 \pm 3.01$ & $4.78 \pm 2.07$ \\
\hline \multicolumn{5}{|l|}{ Msp I-RFLP } \\
\hline M1M2 $n=9$ & $0.255 \pm 0.027$ & $0.080 \pm 0.020$ & $16.20 \pm 6.87$ & $5.49 \pm 1.39$ \\
\hline M2M2 $n=8$ & $0.227 \pm 0.032$ & $0.064 \pm 0.014$ & $15.77 \pm 3.00$ & $4.50 \pm 1.28$ \\
\hline
\end{tabular}

* ₹ For definitions see Table III. 
ied by up to $50 \%$. This variability was related to the apo B genotype of the individual. The group of five subjects with genotype $X I X 1$ had a $22 \%$ higher total FCR than the six who had genotype $X 2 X 2$. More detailed examination of the cause of this difference, using a receptor-blocked LDL tracer, revealed that the difference was due to an increased flux through the receptor pathway. Both the proportion of the plasma LDL apoprotein pool and the amount cleared via receptors was significantly elevated in $X 1 X 1$ individuals. It is unlikely that these observations can be explained by changes of the constitutive activity of the receptor. Rather, they indicate that variations in the structure of the ligand LDL are responsible. Our data suggest that apo B produced in $X 2 X 2$ individuals has a perturbed structure that diminishes its ability to interact with the receptor on cell membranes. Since it is known that only one B protein is present on each particle, this hypothesis also implies that individuals who are heterozygous for the polymorphism would produce two forms of LDL (one receptor active, the other relatively inactive) and would express an intermediate FCR (Table III).

The DNA sequence change that creates the Xba I restriction site occurs at the third base of the codon for threonine 2,488 in apo B (36). No amino acid change results, and so it is unlikely that the Xba I polymorphism itself is functionally significant. Rather, this site is probably in linkage disequilibrium with an important change elsewhere in the coding region. One possibility is that the important mutation lies in the putative receptor binding site (5), i.e., between amino acids 3,1473,157 or $3,351-3,367$, a region close to the Xba I cutting site.

The findings presented here also suggest a mechanism for the association of Xba I genotype and plasma cholesterol in the normal population (12-14). In subjects with normal lipid levels, there is a strong relationship between the receptor-mediated FCR and LDL concentration (31). The observed higher plasma cholesterol in individuals of $X 2 X 2$ versus $X 1 X 1$ genotype thus might be explained by the production of a relatively receptor-inactive apo B in the former group that would lead to accumulation of LDL in the circulation. Where the influence of synthesis becomes predominant, as in our present cohort of hypercholesterolemic patients, this relationship with plasma LDL concentration would be diminished. It is not yet clear whether the metabolic changes described in this study relate to the higher incidence of ischemic heart disease reported in one study to be associated with the $X I$ allele (15). However, if the trend toward higher LDL apoprotein synthesis in the $X 1 X 1$ group (Table IV) is confirmed in subsequent studies, then it may point to the importance of LDL flux and plasma concentration as risk markers for ischemic heart disease.

\section{Acknowledgments}

We are particularly grateful to Mr. R. Young of the Charing Cross Sunley Research Centre for supplying the $\mathrm{PH} 2$ apo B probe. Additionally, we would like to thank Philippa Wells and Joyce Pollock for help in preparing the manuscript.

Th. Demant received a scholarship from Stiftung Volkswagenwerk, Hannover, Federal Republic of Germany. This work was supported by the Charing Cross Sunley Research Trust and by grants from the British Heart Foundation (RG5 and 87/6). The SAAM/CONSAM computer programs were provided by the U. S. Public Health Service/National Institutes of Health/National Heart, Lung, and Blood Institute/ National Cancer Institute joint development.

\section{References}

1. Goldstein, J. L., and M. S. Brown. 1977. The low density lipoprotein pathway and its reaction to atherosclerosis. Annu. Rev. Biochem. 46:897-930.

2. Sparks, J. D., and C. E. Sparks. 1985. Apolipoprotein B and lipoprotein metabolism. Adv. Lipid Res. 21:1-45.

3. Tolleshaug, H., J. L. Goldstein, W. J. Schneider, and M. S. Brown. 1982. Post-translational processing of the LDL receptor and its genetic disruption in familial hypercholesterolemia. Cell. 30:715-724.

4. Lehrman, M. A., W. J. Schneider, T. C. Sudhof, M. S. Brown, J. L. Goldstein, and D. W. Russell. 1985. Mutations in the LDL receptor: Alu-Alu recombination deletes exons encoding transmembrane and cytoplasma domains. Science (Wash. DC). 227:140-146.

5. Knott, T. J., R. J. Pease, S. C. Powell-Wallis, S. C. Rall, T. L. Innerarity, B. Blackhart, W. R. Taylor, A. J. Lusis, B. J. McCarthy, R. W. Mahley, B. Levy-Wilson, and R. J. Scott. 1986. Complete protein sequence and identification of structural domains of human apolipoprotein B. Nature (Lond.). 323:734-738.

6. Lusis, A. J., R. West, M. Mehrabian, M. A. Reuben, R. C. LeBoeuf, J. S. Kaptein, D. F. Johnson, V. N. Schumaker, M. P. Yuhasz, M. C. Schotz, and J. Elovson. 1985. Cloning and expression of apolipoprotein B, the major protein of low and very low density lipoproteins. Proc. Natl. Acad. Sci. USA. 82:4597-4601.

7. Knott, T. J., S. C. Rall, T. L. Innerarity, S. F. Jacobson, M. S. Urdea, B. Levy-Wilson, L. M. Powell, R. J. Pease, R. Eddy, H. Nakai, M. Byers, L. M. Priestley, E. Robertson, L. B. Rall, C. Betsholtz, T. B. Shows, R. W. Mahley, and J. Scott. 1985. Human apolipoprotein B: carboxyl-terminal domains, sites of gene expression, and chromosomal localization. Science (Wash. DC). 230:37-43.

8. Carlsson, P., S. O. Olofsson, G. Bondjers, C. Darnfors, O. Wiklund, and G. Bjursell. 1985. Cloned human apolipoprotein B cDNA detects a 20,000 bases long mRNA. Nucleic Acid Res. 13:8813-8824.

9. Shoulders, C. C., N. B. Myant, A. Sidoli, J. C. Rodriguez, C. Cortese, F. E. Baralle, and R. Cortese. 1985. Molecular cloning of human LDL apolipoprotein B cDNA. Evidence for more than one gene per haploid genome. Atherosclerosis. 58:277-289.

10. Preistley, L., T. Knott, S. Wallis, L. Powell, R. Pearse, A. Simon, and J. Scott. 1985. RFLP for the human apolipoprotein B gene. Nucleic Acid Res. 13:6789-6794.

11. Barni, N., P. J. Talmud, and P. Carlsson. 1986. The isolation of genomic recombinants for the human apolipoprotein B gene, and the mapping of three common DNA polymorphisms of the gene: a useful marker for human chromosome 2. Hum. Genet. 73:4313-4319.

12. Law, A., L. M. Powell, H. Brunt, T. J. Knott, D. G. Altman, J. Rejput, S. C. Wallis, R. J. Pearse, L. M. Priestley, J. Scott, G. J. Miller, and N. E. Miller. 1986. Common DNA polymorphism within coding sequence of apolipoprotein $\mathrm{B}$ gene associated with altered lipid levels. Lancet. i:1301-1303.

13. Talmud, P. J., N. Barni, A. M. Kessling, P. Carlsson, C. Darnfors, G. Bjursell, D. Galton, V. Wynn, H. Kirk, M. R. Hayden, and S. E. Humphries. 1987. Apolipoprotein B gene variants are involved in the determination of serum cholesterol levels: a study in normo and hyperlipidaemic individuals. Atherosclerosis. 67:81-89.

14. Berg, K. 1986. DNA polymorphism at the apolipoprotein B locus is associated with lipoprotein levels. Clin. Genet. 30:515-520.

15. Hegele, R. A., L. Huang, P. N. Herbert, C. B. Blum, J. E. Buring, C. H. Hennekens, and J. L. Breslow. 1986. Apolipoprotein B gene polymorphism associated with myocardial infarction. N. Engl. J. Med. 315:1509-1515.

16. Deeb, S., A. Failor, B. G. Brown, J. D. Brunzell, J. J. Albers, and A. G. Motulsky. 1986. Molecular genetics of apolipoproteins and coronary heart disease. Cold Spring Harbor Symp. LI:403-409.

17. Brown, M. S., and J. L. Goldstein. 1975. Familial hypercholesterolemia. Genetic, biochemical and pathophysiologic considerations. Adv. Intern. Med. 20:273-296.

18. Shepherd, J., S. Bicker, A. R. Lorimer, and C. J. Packard. 1979. 
Receptor mediated low density lipoprotein catabolism in man. $J$. Lipid. Res. 20:999-1006.

19. Shepherd, J., C. J. Packard, S. Bicker, T. D. V. Lawrie, and H. G. Morgan. 1980. Cholestyramine promotes receptor mediated low density lipoprotein catabolism. N. Engl. J. Med. 302:1219-1222.

20. Patsch, J. R., S. Sailer, G. Kostner, F. Sandhofer, A. Holaseck, and H. Braunsteiner. 1974. Separation of the main lipoprotein density classes from human plasma by rate zonal ultracentrifugation. J. Lipid. Res. 15:356-366.

21. McFarlane, A. S. 1958. Efficient trace labelling of proteins with iodine. Nature (Lond.). 182:53.

22. Mahley, R. W., T. L. Innerarity, R. E. Pitas, K. H. Weisgraber, J. H. Brown, and E. Gross. 1977. Inhibition of lipoprotein binding to cell surface receptors of fibroblasts following selective modification of arginyl residues in arginine-rich and B apoproteins. J. Biol. Chem. 252:7279-7287.

23. Berman, M., and M. F. Weiss. 1978. SAAM Manual, Department of Health, Education and Welfare, Washington DC. Publication No. (NIH) 78-180.

24. Langer, T., W. Strober, and R. I. Levy. 1972. The metabolism of low density lipoprotein in familial type II hyperlipoproteinemia. $J$. Clin. Invest. 51:1528-1537.

25. Kunkel, L. M., D. K. Smith, S. H. Boyer, D. S. Borgoankar, S. S. Wachtel, O. J. Miller, H. W. Jones, and J. M. Rary. 1977. Analysis of human Y-chromosome-specific reiterated DNA in chromosome variants. Proc. Natl. Acad. Sci. USA. 74:1245-1249.

26. Humphries, S. E., A. M. Kessling, B. Horsthemke, J. A. Donald, M. Seed, N. Jowett, M. Holm, D. J. Galton, V. Wynn, and R. Williamson. 1985. A common DNA polymorphism of the low density lipoprotein (LDL) receptor gene and its use in diagnosis. Lancet. i: $1003-1005$.

27. Kotze, M. J., E. Langenhoren, E. Dietzsch, and A. E. Reitief.
1987. A RFLP associated with the low density lipoprotein receptor gene (LDLR). Nucleic Acid Res. 15:376.

28. Kessling, A. M., B. Horsthemke, and S. E. Humphries. 1985. A study of DNA polymorphisms around the human apolipoprotein AI gene in hyperlipidaemia and normal individuals. Clin. Genet. 28:296306.

29. Coleman, R. T., P. A. Gonzales, H. Funke, G. Assmann, B. Levy-Wilson, and P. M. Frossard. 1986. Polymorphisms in the apolipoprotein AI-CIII complex. Mol. Biol. \& Med. 3:213-228.

30. Feinberg, A. P., and B. Vogelstein. 1984. Addendum to "A technique for radiolabelling DNA restriction endonuclease fragments to high specific activity." Anal. Biochem. 137:266-267.

31. Packard, C. J., and J. Shepherd. 1983. Low density lipoprotein receptor pathway in man: its role in regulating plasma low density lipoprotein levels. Atheroscler. Rev. 11:29-63.

32. Packard, C. J., J. L. H. C. Third, J. Shepherd, A. R. Lorimer, H. G. Morgan, and T. D. V. Lawrie. 1976. Low density lipoprotein metabolism in a family of familial hypercholesterolemic patients. Metab. Clin. Exp. 25:995-1005.

33. Packard, C. J., L. McKinney, K. Carr, and J. Shepherd. 1983. Cholesterol feeding increases low density lipoprotein synthesis. J. Clin. Invest. 72:45-51.

34. Slater, H. R., L. McKinney, C. J. Packard, and J. Shepherd. 1984. Contribution of the receptor pathway to low density lipoprotein catabolism in humans. Arteriosclerosis. 4:604-613.

35. Kesaniemi, Y. A., J. L. Witztum, and U. P. Steinbrecher. 1983. Receptor-mediated catabolism of low density lipoprotein in man. $J$. Clin. Invest. 71:950-959.

36. Carlsson, P., C. Darnfors, S. Oloffson, and G. Bjursell. 1986. Analysis of the human apolipoprotein B gene: complete structure of the B74 region. Gene (Amst.). 49:29-51. 